\title{
Study on Use of Lactoferrin for the Biopreservation of Paneer
}

\author{
C.S.S. Shashikumar and D.B. Puranik ${ }^{1 *}$ \\ Department of Dairy Technology, Dairy Science College \\ Hebbal, Bangalore-560024, Karnataka \\ India
}

\begin{abstract}
Paneer is an Indian traditional milk product which occupies an important place as a base product for the production of various culinary preparations. The shelflife of paneer is a major constraint in its utilization. Lactoferrin, a member of transferrin family of proteins, is one of the most important milk proteins naturally found in the milk of mammals and is an iron-binding glycoprotein which has antimicrobial properties. Studies were conducted on incorporation of lactoferrin at different levels $(10,15 \& 20$ ppm) in paneer. It was observed that, as the level of lactoferrin in the product increased, there was a significant decrease in the bacterial growth when compared to the control; thereby increasing the shelflife of paneer. Lactoferrin-treated paneer, up to $20 \mathrm{ppm}$ showed an increase in shelf life up to 7 days at room temperature $\left(30^{\circ} \mathrm{C}\right)$ and 15 days at refrigerated temperature $\left(4^{\circ} \mathrm{C}\right)$ compared with the control with a shelf life of 2 days at $30^{\circ} \mathrm{C}$ and 7 days at $4{ }^{\circ} \mathrm{C}$, respectively. Similarly, as the level of lactoferrin increases, paneer had significantly higher hardness, cohesiveness, springiness and chewiness. The sensory evaluation of the paneer samples treated with $20 \mathrm{ppm}$ lactoferrin was acceptable up to 7 days at ambient temperature and up to 15 days at refrigerated temperature.
\end{abstract}

Keywords: Biopreservation, lactoferrin, paneer

\section{INTRODUCTION}

India is the largest producer of milk with a production of over 108.5 million tones per annum in year 2008-2009 (Khanna, 2010). About $55 \%$ of the total milk produced in the country is being utilized for preparation of various indigenous dairy products like paneer, chhana and chhana-based sweets, khoa and khoa-based sweets and fermented milk products etc. One of the major disadvantages of these traditional milk products, especially with paneer, is the low keeping quality and shelf life. The use of chemical preservatives to inhibit growth of spoilage bacteria in these products has been recognized as a deterrent to health because of their potential toxicity and the regulatory authorities have virtually banned the chemical preservatives to be used in these products. Hence, there is a considerable interest in the possible use of natural biopreservatives in these traditional milk products (Makhal, 2000). Various physiological functions like bacteriostatic, antimicrobial etc. have been reported for lactoferrin and these properties of lactoferrin have opened up a new approach to food safety (Weinberg, 2007). The lactoferrin isolated from whey and milk has a great potential to be used as biopreservative in extending the shelf life of traditional Indian dairy products. This study investigates the use of optimum level of lactoferrin for extending the shelf life of paneer.

${ }^{1}$ Department of Dairy Technology, Dairy Science College, Bangalore, Karnataka, India Author for correspondence: dbpuranik@yahoo.com 


\section{MATERIALS AND METHODS}

\section{Preparation of paneer}

Paneer was prepared as per the procedure recommended by Sachdeva et al. (1991) with a slight modification.

\section{Isolation of lactoferrin}

Lactoferrin was isolated in the laboratory from cheese whey by gel filtration as per the method outlined by Oram and Reiter (1968).

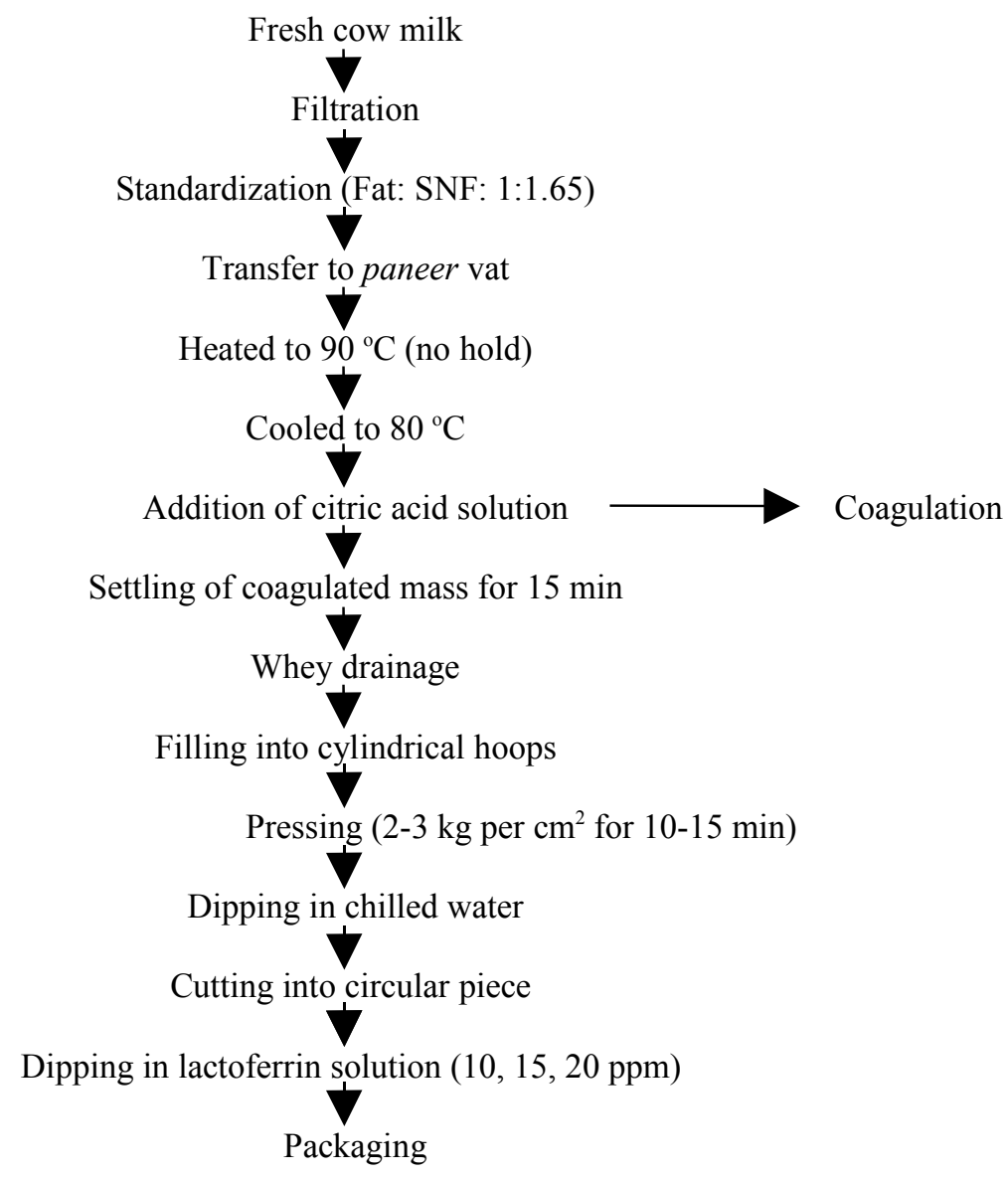

Fig. 1. Flow diagram for manufacturing paneer

\section{Citical Dfference (CD)}

Raw paneer cut in to pieces of $1 \mathrm{~cm}$ cubes, was given surface treatment, that is, dipped in lactoferrin solution of different concentrations viz., 10, 15, and $20 \mathrm{ppm}$. The lactoferrintreated paneer was subjected to physicochemical, microbial analysis and sensory evaluation for acceptability. Treated paneer was packed in Low Density Polyethylene (LDPE) and 
stored at room temperature $\left(30 \pm 1{ }^{\circ} \mathrm{C}\right)$ and refrigerated temperature $\left(4 \pm 1{ }^{\circ} \mathrm{C}\right)$ in order to study the preservative effect of lactoferrin on paneer.

Chemical analysis of paneer

Fat content in paneer was estimated by Gerber method as per the procedure given in IS: SP18 (part XI) (1981). Moisture, protein and ash content were estimated according to IS: SP18 (part XI) (1981).

\section{Microbiological quality of paneer}

Paneer samples were analyzed for total bacterial count, coliform count, yeast and mold count using selective agar media (HI-MEDIA Laboratories Pvt. Ltd., Mumbai). The ingredients were dissolved in distilled water by steaming, cooled, $\mathrm{pH}$ adjusted to 7.0 and autoclaved at $121^{\circ} \mathrm{C}$ for $15 \mathrm{~min}$.

\section{Texture analysis of paneer}

Texture Profile Analysis (TPA) parameters were determined by using the Stable MicroSystem TA-XT plus Texture Analyzer (UK) fitted with $25 \mathrm{~kg}$ load cell for two- stage linear compression of paneer samples.

\section{Sensory evaluation}

Sensory evaluation was carried out by serving control and experiment samples, to a panel of five experts. The samples were examined for colour and appearance, body and texture, flavor and overall acceptability on a 9-point Hedonic scale. The scores given by the panel of judges were then statistically analyzed (Dharampal \& Gupta, 1985).

\section{Storage studies}

The samples were subjected to storage studies both at room temperature $\left(30 \pm 1{ }^{\circ} \mathrm{C}\right)$ and refrigeration temperature $\left(4 \pm 1{ }^{\circ} \mathrm{C}\right)$ along with a control. The analysis of the stored samples was carried out at regular intervals of storage.

\section{Statistical analysis}

The data were analyzed statistically for test of significance as per the procedure outlined by Siegal and Castlellan (1988). All the statistical tests were carried out at $5 \%$ level of significance and all the data were analyzed using statistical packages for social sciences (SPSS version 10).

\section{RESULTS AND DISCUSSION}

\section{Microbial quality}

The results of the effect of lactoferrin on the microbial growth are shown in (Tables 1 and 2). The control sample showed total bacterial count, coliform count and yeast and mold count of $3.40-6.74 \log _{10} \mathrm{cfu} / \mathrm{g}, 1.74-3.52 \log _{10} \mathrm{cfu} / \mathrm{g}$ and $1.33-2.48 \log _{10} \mathrm{cfu} / \mathrm{g}$, respectively from 0 to $6^{\text {th }}$ day. The total bacterial count, coliform count and yeast and mould count increased 
proportionally. In case of lactoferrin incorporated paneer, there was no such increase and the total bacterial count, coliform count and yeast and mold count decreased significantly compared to the control paneer, the decrease being maximum in case of $20 \mathrm{ppm}$ lactoferrin treated paneer. This clearly shows the bactericidal effect of lactoferrin in paneer, in combating the microbial growth. Batish et al. (1988), reported the bacteriostastic activity of natural lactoferrin against a wide range of microorganisms including Garm negative and also against some Gram-positive organisms. The results of the present study are in agreement with the result of above authors.

The microbial quality of control and lactoferrin treated sample packed in LDPE, stored at refrigeration temperature is presented in Table 3. In case of control the total bacterial count, coliform and yeast and mold counts increased from 3.46 to $7.68 \log _{10} \mathrm{cfu} / \mathrm{g}, 1.74$ to 3.68 and 1.33 to $3.27 \log _{10} \mathrm{cfu} / \mathrm{g}$ from 0 to $12^{\text {th }}$ day of storage, respectively. In case of samples treated with lactoferrin at 10, 15 and $20 \mathrm{ppm}$ concentrations, Total Bacterial Count, Coliform count and Yeast and Mold count increased marginally, with the maximum bacteriocidal effect of lactoferrin in case of $20 \mathrm{ppm}$ lactoferrin incorporated product. Lu et al. (2008) studied the antimicrobial activity of lactoferrin by Oxford cup method. The antimicrobial effect increased with the decrease of iron saturation. Richard (2003) reported that activity of lactoferrin was more at refrigeration temperature. Normal paneer without any preservatives can be kept for only 2 days at ambient temperature and 6 days at refrigerated temperature (Sachdeva, 1983).

Table 1. Effect of lactoferrin on microbial count of paneer packed in LDPE stored at $30 \pm 1^{\circ} \mathrm{C}$

\begin{tabular}{|c|c|c|c|c|c|c|c|c|c|c|c|c|c|}
\hline \multirow{3}{*}{ Storage } & \multicolumn{12}{|c|}{$\log _{10}(\mathrm{cfu} / \mathrm{g})$} & \multirow{3}{*}{ CD } \\
\hline & \multicolumn{3}{|c|}{ Control } & \multicolumn{3}{|c|}{10 (ppm) } & \multicolumn{3}{|c|}{15 (ppm) } & \multicolumn{3}{|c|}{20 (ppm) } & \\
\hline & TBC & $\mathrm{C}$ & Y\&M & TBC & $\mathrm{C}$ & Y\&M & TBC & $\mathrm{C}$ & Y\&M & TBC & $\mathrm{C}$ & Y\&M & \\
\hline 0 & 3.4 & 1.74 & 1.33 & 3.4 & 1.72 & 1.3 & 3.42 & 1.72 & 1.32 & 3.40 & 1.74 & 1.32 & 0.02 \\
\hline 2 & 4.8 & 2.34 & 1.94 & 4.64 & 2.28 & 1.90 & 4.58 & 2.24 & 1.74 & 4.25 & 2.10 & 1.68 & 0.23 \\
\hline 4 & 5.88 & 2.98 & 2.44 & 5.78 & 2.88 & 2.22 & 5.74 & 2.86 & 2.20 & 5.56 & 2.48 & 1.90 & 0.16 \\
\hline 6 & 6.74 & 3.52 & 2.84 & 6.58 & 3.44 & 2.54 & 6.42 & 3.42 & 2.36 & 6.24 & 3.34 & 2.20 & 0.14 \\
\hline
\end{tabular}

*All values are average of three trials

TBC- total bacterial count, Y\&M- yeast and mold, C- Coliform count

Table 2. Effect of lactoferrin on microbial count of paneer packaged in LDPE stored at $4 \pm 1^{\circ} \mathrm{C}$

\begin{tabular}{|c|c|c|c|c|c|c|c|c|c|c|c|c|c|}
\hline \multirow{3}{*}{$\begin{array}{l}\text { Storage } \\
\text { (day) }\end{array}$} & \multicolumn{9}{|c|}{$\log _{10}(\mathrm{cfu} / \mathrm{g})$} & \multirow{2}{*}{\multicolumn{3}{|c|}{20 (ppm) }} & \multirow{3}{*}{ CD } \\
\hline & \multicolumn{3}{|c|}{ Control } & \multicolumn{3}{|c|}{10 (ppm) } & \multicolumn{3}{|c|}{15 (ppm) } & & & & \\
\hline & TBC & C & $\mathbf{Y} \& \mathbf{M}$ & TBC & C & Y\&M & TBC & C & Y\&M & TBC & $\mathbf{C}$ & Y\&M & \\
\hline 0 & 3.46 & 1.74 & 1.33 & 3.42 & 1.70 & 1.30 & 3.40 & 1.68 & 1.32 & 3.44 & 1.74 & 1.32 & 0.02 \\
\hline 2 & 4.24 & 1.90 & 1.64 & 4.00 & 1.82 & 1.58 & 3.78 & 1.80 & 1.48 & 3.68 & 1.78 & 1.40 & 0.12 \\
\hline 4 & 5.18 & 2.12 & 1.78 & 4.64 & 1.96 & 1.70 & 4.52 & 1.90 & 1.69 & 4.26 & 1.83 & 1.52 & 0.16 \\
\hline 6 & 5.92 & 2.34 & 1.94 & 5.56 & 2.12 & 1.84 & 4.98 & 2.02 & 1.78 & 4.68 & 2.00 & 1.68 & 0.24 \\
\hline 8 & 6.28 & 2.58 & 2.24 & 5.84 & 2.44 & 2.08 & 5.54 & 2.24 & 1.89 & 5.1 & 2.18 & 1.79 & 0.30 \\
\hline 10 & 6.92 & 3.08 & 2.60 & 6.46 & 2.86 & 2.38 & 6.17 & 2.52 & 1.96 & 5.54 & 2.38 & 1.90 & 0.22 \\
\hline 12 & 7.40 & 3.48 & 3.18 & 7.16 & 3.42 & 2.80 & 6.92 & 2.94 & 2.24 & 6.08 & 2.74 & 2.05 & 0.28 \\
\hline
\end{tabular}




\begin{tabular}{llllllllllllll}
\hline 14 & 7.68 & 3.68 & 3.27 & 7.40 & 3.46 & 3.00 & 7.16 & 3.40 & 2.84 & 6.92 & 3.34 & 2.55 & 0.40 \\
\hline
\end{tabular}

*All values are average of three trials

TBC- total bacterial count, Y\&M- yeast and mold, C- Coliform count

Chemical composition

The fresh and stored lactoferrin treated paneer at different levels were subjected to chemical analysis and the results obtained during the process are shown in Table 3. In case of fresh control paneer the moisture, fat, protein and ash contents were 53.90, 24.80, 17.60 and 1.40 per cent, respectively. Whereas paneer treated with $20 \mathrm{ppm}$ lactoferrin had the moisture, fat, protein and ash content of $54.50 \%, 24.50 \%, 17.38 \%$ and $1.32 \%$, respectively. The moisture content of lactoferrin treated paneer samples increased with the increase in the level of lactoferrin. Similar observations were made in case of stored lactoferrin treated paneer.

Table 3. Effect of different levels of lactoferrin on chemical composition of fresh paneer

\begin{tabular}{lcccccccc}
\hline \multirow{2}{*}{$\begin{array}{l}\text { Concentration } \\
\text { Levels }\end{array}$} & \multicolumn{7}{c}{ Moisture } & \multicolumn{2}{c}{ Fat } & \multicolumn{2}{c}{ Protein } & \multicolumn{2}{c}{ Ash } \\
\cline { 2 - 9 } & Fresh & Stored & Fresh & Stored & Fresh & Stored & Fresh & Stored \\
\hline Control & 53.90 & 53.80 & 24.80 & 24.85 & 17.61 & 17.75 & 1.40 & 1.45 \\
$10 \mathrm{ppm}$ & 54.20 & 54.00 & 24.72 & 24.80 & 17.50 & 17.58 & 1.38 & 1.40 \\
$15 \mathrm{ppm}$ & 54.35 & 54.20 & 24.60 & 24.72 & 17.42 & 17.52 & 1.37 & 1.39 \\
$20 \mathrm{ppm}$ & 54.50 & 54.35 & 24.50 & 24.55 & 17.38 & 17.43 & 1.32 & 1.35 \\
CD & 0.25 & 0.25 & 0.08 & 0.08 & 0.15 & 0.16 & 0.08 & 0.08 \\
\hline
\end{tabular}

*All values are average of three trials

\section{Rheological characteristics}

The rheological characteristics of fresh and stored paneer treated with lactoferrin are presented in Table 4. The lactcoferrin treated paneer had significantly lower hardness (14.384), cohesiveness (0.601), springiness (0.736), chewiness (6.368) than the control sample. The decrease in the hardness of lactoferrin treated products could be due to higher moisture content. The finding of this study related to untreated paneer is in accordance with Desai et al. (1991) who studied the rheological properties of market paneer.

Table 4. Effect of lactoferrin incorporation on rheological characteristics of fresh and stored paneer

\begin{tabular}{lllllllll}
\hline & \multicolumn{6}{c}{ Rheological characteristics } \\
\cline { 2 - 8 } Sample & \multicolumn{6}{c}{ Fresh paneer } & \multicolumn{5}{c}{ Stored paneer } \\
\cline { 2 - 9 } & Hardness & Cohesiveness & Springiness & Chewiness & Hardness & Cohesiveness & Springiness & Chewiness \\
\hline Control & 17.416 & 0.645 & 0.767 & 8.625 & 17.560 & 0.657 & 0.767 & 8.864 \\
$10 \mathrm{ppm}$ & 17.235 & 0.598 & 0.753 & 7.775 & 17.340 & 0.627 & 0.760 & 8.276 \\
$15 \mathrm{ppm}$ & 16.359 & 0.589 & 0.743 & 7.170 & 16.574 & 0.613 & 0.756 & 7.956 \\
$20 \mathrm{ppm}$ & 14.384 & 0.601 & 0.736 & 6.368 & 14.608 & 0.616 & 0.735 & 6.623 \\
CD & 0.0064 & 0.0064 & 0.0049 & 0.0094 & 0.007 & 0.003 & 0.006 & 0.004 \\
\hline
\end{tabular}

*All values are average of three trials 


\section{Sensory characteristics}

The sensory scores with regard to the effect of incorporation of lactoferrin for colour and appearance, body and texture, flavor and overall acceptability are presented in Table 5. The overall acceptability scores were 7.70 in the control, compared to 7.51, 7.46 and 7.33 for 10 , 15 and $20 \mathrm{ppm}$ in lactoferrin-treated paneer, respectively. The overall acceptability of paneer samples treated with lactoferrin at different levels did not vary significantly and were similar to the control. Hence it could be inferred that lactoferin could be incorporated up to $20 \mathrm{ppm}$ concentration in paneer samples without significant changes in the sensory attributes of paneer.

Table 5. Effect of incorporation of different levels of lactoferrin on sensory characteristics of paneer

\begin{tabular}{lcccc}
\hline Concentration levels & $\begin{array}{c}\text { Color \& } \\
\text { appearance }\end{array}$ & Body \& texture & Flavor & Overall acceptance \\
\hline Control & 8.11 & 7.72 & 7.27 & 7.70 \\
$10 \mathrm{ppm}$ & 7.78 & 7.52 & 7.24 & 7.51 \\
$15 \mathrm{ppm}$ & 7.60 & 7.45 & 7.23 & 7.46 \\
$20 \mathrm{ppm}$ & 7.45 & 7.32 & 7.22 & 7.33 \\
CD & 0.13 & 0.17 & 0.08 & 0.20 \\
\hline
\end{tabular}

*All values are average of three trials

\section{CONCLUSIONS}

Lactoferrin was incorporated in paneer at three different levels viz, 10,15 and $20 \mathrm{ppm}$. The microbiological counts of paneer stored at room temperature $\left(30 \pm 1{ }^{\circ} \mathrm{C}\right)$ and as well as at refrigerated temperature $\left(4 \pm 1{ }^{\circ} \mathrm{C}\right)$ were estimated at every three day-interval. The growth of total bacterial count, coliform and yeast and mold counts in control sample were observed to be higher when compared to experimental paneer samples. The paneer sample treated with $20 \mathrm{ppm}$ had significantly lower microbial growth, thus indicating the higher keeping quality upto 6 days at room temperature $\left(30 \pm 1{ }^{\circ} \mathrm{C}\right)$. Similar observations were made in case of paneer treated with $20 \mathrm{ppm}$ lactoferrin and stored at refrigeration temperature $\left(4 \pm 1{ }^{\circ} \mathrm{C}\right)$, where the keeping quality was observed to be 14 days. Hence, lactoferrin could be easily used as a biopreservative for extending the shelflife of paneer.

\section{REFERENCES}

Batish, V.K., Chander, H., Zumdegeni, K.C., Bhatia, K.L. and Singh, R.S. (1988). Antibacterial activity of lactoferrin against some common food-borne pathogenic organisms. Aust. J. of Dairy Tech. 5, 16-18.

Desai, H.K., Gupta, S.K., Patel, A.A. and Patel, G.R. (1991). Studies on texture of paneer. Jap. J. Dairy. Food Sci. 40(1), A14-A21. 
Dharam Pal, P.V. and Gupta, S.K. (1985). Sensory evaluation of dairy products. Indian Dairyman 34(3), 473-477.

IS: SP 18 part XI, (1981). ISI hand book of food analysis, Dairy products, Bureau of Indian standard, Manak Bhavan, New Delhi, India.

Khanna. R.S. and Sharad Gupta, (2010). Market efficiency: Key to Indian Dairy Sector. Proceedings of $38^{\text {th }}$ Dairy Industry Conference, pp18-31.

Lu,R.R., Xu,S., Yang,R. and Sun, Z. (2008). Antimicrobial activity of lactoferrin and its mechanism involved. Food Sci. China. 29(2), 238-243.

Makhal, S. (2000). Preservation of paneer with 'GRAS' additives- M.Tech. Dissertation. West Bengal Univ. Animal and Fishery Sciences, Mohanpur Campus, Nadia (WB). pp: 126-129.

Oram, J.D, and Reiter, B., (1968). Inhibition of bacteria by lactoferrin and other chelating agents. Biochem. Biophys. Acta, 170: 351.

Richard, A.H. (2003). Use of lactoferrin and lactoferricin to inhibit growth of food patens and spoilage microorganisms in meat. Agri. Food Research and Development Initiative. ARDI-Project \# 01-521.

Sachdeva, S. (1983). Production, packaging and preservation of Paneer. Ph.D. Thesis submitted to Kurukshetra University, Kurukshetra, Haryana, India.

Sachdeva, S., Prokopek, D. and Reuter, H. (1991). Technology of paneer form cow milk. Japaneese J. Dairy and Food Sci. 40(2), A85-A90.

Siegel, S. and Castlellan, J.N. (1988). Non-parametric Statistics, Second Edition, McGraw-Hill International Editions, U.S.

Weinberg, E.D. (2007). Antibiotic properties and applications of lactoferrin. Curr. Pharm. Design, 13, 801-811. 